\title{
Long-Term Potentiation at Cerebellar Parallel Fiber-Purkinje Cell Synapses Requires Presynaptic and Postsynaptic Signaling Cascades
}

\author{
De-Juan Wang, ${ }^{1}$ Li-Da Su, ${ }^{1,2}$ Ya-Nan Wang, ${ }^{1}$ Dong Yang, ${ }^{1}$ Cheng-Long Sun, ${ }^{1}$ Lin Zhou, ${ }^{1}$ Xin-Xin Wang, ${ }^{1}$ and Ying Shen ${ }^{1}$ \\ ${ }^{1}$ Department of Neurobiology, Key Laboratory of Medical Neurobiology of the Ministry of Health, Zhejiang Province Key Laboratory of Neurobiology, \\ Zhejiang University School of Medicine, Hangzhou, China, and ${ }^{2}$ Neuroscience Care Unit, Second Affiliated Hospital of Zhejiang University School of \\ Medicine, Hangzhou, 310058 China
}

\begin{abstract}
Long-term depression (LTD) and long-term potentiation (LTP) at cerebellar parallel fiber-Purkinje cell (PF-PC) synapses play critical roles in motor learning. The $1 \mathrm{~Hz}$ stimulation at PF-PC synapses induces a postsynaptically expressed LTP that requires a postsynaptic $\mathrm{Ca}^{2+}$ transient, phosphatases, and nitric oxide (NO). However, the mechanism underlying $1 \mathrm{~Hz}$ PF-LTP remains unclear because none of the known events is related to each other. Here, we demonstrated that $1 \mathrm{~Hz}$ PF-LTP requires postsynaptic cytosolic phospholipase $\mathrm{A}_{2} \alpha$ $\left(\mathrm{CPLA}_{2} \alpha\right) /$ arachidonic acid (AA) signaling and presynaptic endocannabinoid receptors. Using patch-clamp recording in cerebellar slices, we found that $1 \mathrm{~Hz}$ PF-LTP was abolished in $\mathrm{CPLA}_{2} \alpha$-knock-out mice. This deficit was effectively rescued by the conjunction of $1 \mathrm{~Hz}$ PF stimulation and the local application of AA. 2-Arachidonoylglycerol and the retrograde activation of cannabinoid receptor 1 (CB1R) were also involved in $1 \mathrm{~Hz}$ LTP because it was blocked by the hydrolysis of 2-AG or by inhibiting CB1Rs. The amount of NO released was detected using an NO electrode in cultured granule cells and PF terminals. Our results showed that the activation of CB1Rs at PF terminals activated NO synthetase and promoted NO production. The $1 \mathrm{~Hz}$ PF-stimuli evoked limited NO, but $100 \mathrm{~Hz}$ PF stimulation generated a large amount. Therefore, $1 \mathrm{~Hz}$ PF-LTP, distinct from classical postsynaptically expressed plasticity, requires concurrent presynaptic and postsynaptic activity. In addition, NO of sufficient amplitude decides between the weakening and strengthening of PF-PC synapses.
\end{abstract}

Key words: arachidonic acid; $\mathrm{CPLA}_{2} \alpha$; endocannabinoids; long-term potentiation; parallel fiber; Purkinje cell

\section{Introduction}

Long-term use-dependent alterations in synaptic strength underlie information storage in the brain. In the cerebellum, long-term depression (LTD) at parallel fiber-Purkinje cell (PF-PC) synapses promotes adaptation of the vestibulo-ocular reflex and eye-blink conditioning (De Zeeuw et al., 1998; Ito, 2001; Feil et al., 2003; Boyden et al., 2006; Hansel et al., 2006). Meanwhile, long-term potentiation (LTP) at PF-PC synapses causes the extinction of learned associations in trained animals (Han et al., 2000; Medina

Received Sept. 23, 2013; revised Dec. 7, 2013; accepted Jan. 8, 2014.

Author contributions: D.-J.W. and Y.S. designed research; D.-J.W., L.-D.S., Y.-N.W., D.Y., C.-L.S., L.Z., and X.-X.W. performed research;X.-X.W. contributed unpublished reagents/analytic tools;D.-J.W., L.-D.S., Y.-N.W., D.Y.,C.-L.S., and Y.S. analyzed data; D.-J.W. and Y.S. wrote the paper.

Part of the present findings have been reported as a preliminary abstract: Su LD, Wang DJ, Yang D, Shen Y, Hu YH (2013) Retrograde $\mathrm{CPLA}_{2} \alpha /$ arachidonic acid/2-AG signaling is essential for cerebellar depolarization-induced suppression of excitation and long-term potentiation. Cerebellum 12:297-299. Abstract for Proceedings of the Fifth International Symposium of Society of Research on Cerebellum in China. This work was supported by the National Basic Research Program of the Ministry of Science and Technology of China Grants 2009CB941400 and 2011CB504400, the National Natural Science Foundation of China Grants 31070945, 31271148, and 31100780, and the Ministry of Education of China New Century Talent Award NCET-07-0751. We thank Dr. Adam Sapirstein (Johns Hopkins University, Baltimore, MD) for kindly providing $\mathrm{CPLA}_{2} \alpha$ knock-out mice, Dr. lain C. Bruce for reading the manuscript, and members of the Y.S. laboratory for helpful advice.

The authors declare no competing financial interests.

Correspondence should be addressed to Dr. Ying Shen, 866 Yu Hang Tang Road, Hangzhou, Zhejiang 310058, China. E-mail: yshen@zju.edu.cn.

DOI:10.1523/JNEUROSCI.4064-13.2014

Copyright $\odot 2014$ the authors $\quad 0270-6474 / 14 / 342355-10 \$ 15.00 / 0$ et al., 2000; Schonewille et al., 2010). The reversible change in synaptic efficacy resulting from PF-LTD and PF-LTP is suggested to be the resetting mechanism for motor learning (Sejnowski, 1977; Houk and Wise, 1995; Medina et al., 2000). Evidence from fish and rat cerebellum demonstrated that PF-LTD and PF-LTP can reverse each other (Han et al., 2000; Lev-Ram et al., 2003).

PF-PC synapses undergo two forms of LTP, which are expressed either presynaptically or postsynaptically depending on stimulus frequency (Jörntell and Hansel, 2006). Upon PF stimulation at $4-8 \mathrm{~Hz}$, presynaptically expressed LTP is evoked via presynaptic cyclic adenosine monophosphate signaling (Salin et al., 1996; Chen and Regehr, 1997; Linden and Ahn, 1999). Distinctly, $1 \mathrm{~Hz}$ PF stimulation induces postsynaptically expressed LTP because presynaptic glutamate release does not change and the serine/threonine phosphatases at postsynaptic $\alpha$-amino-3hydroxy-5-methyl-4-isoxazolepropionic acid receptors (AMPARs) are required (Lev-Ram et al., 2002; Belmeguenai and Hansel, 2005; Schonewille et al., 2010). The postsynaptically expressed LTP is suggested to be the extinguishing mechanism for LTD because it reverses LTD and vice versa, whereas the presynaptically expressed LTP leaves LTD still saturated (LevRam et al., 2003). Thus, investigating how $1 \mathrm{~Hz}$ PF-LTP is induced is important for understanding the mechanisms of motor learning.

The $1 \mathrm{~Hz}$ PF stimulation evokes a small $\mathrm{Ca}^{2+}$ transient (Coesmans et al., 2004), which is required for the induction of LTP 
because the $\mathrm{Ca}^{2+}$ chelator, BAPTA, blocks such LTP (Coesmans et al., 2004). The 1 Hz LTP also depends on nitric oxide (NO) because an inhibitor of nitric oxide synthase (NOS) or trapping NO blocks it (Lev-Ram et al., 2002, 2003). Despite these findings, most of the signaling underlying $1 \mathrm{~Hz}$ PF-LTP remains unclear. For example, the link between postsynaptic $\mathrm{Ca}^{2+}$ transient and NO production is unknown. In the present work, we aimed to investigate the signaling molecules involved in $1 \mathrm{~Hz}$ LTP. Our results indicate that the induction of $1 \mathrm{~Hz}$ PF-LTP requires both presynaptic and postsynaptic events, distinct from previously recognized plasticity. Interestingly, $1 \mathrm{~Hz}$ PF-LTP and PF-LTD share several signaling molecules, including $\mathrm{Ca}^{2+}$, cytosolic phospholipase $\mathrm{A}_{2} \alpha\left(\mathrm{CPLA}_{2} \alpha\right)$, and NO, that may work as bidirectional messengers to balance the induction of LTP and LTD.

\section{Materials and Methods}

Slice preparation. All experiments were approved by the Animal Experimentation Ethics Committee of Zhejiang University and were specifically designed to minimize the number of animals used. Original breeding pairs of the $\mathrm{CPLA}_{2} \alpha$ knock-out (KO) strain were obtained from Dr. Adam Sapirstein (Johns Hopkins University, Baltimore, MD) and maintained at the Experimental Animal Center of Zhejiang University. Mice were kept under temperature-controlled conditions on a 12:12 h light/dark cycle with food and water ad libitum. Sagittal slices of cerebellar vermis $(250 \mu \mathrm{m})$ were prepared from P17-P23 anesthetized mice of either sex using a vibrating tissue slicer (Leica VT1000S) and ice-cold standard artificial CSF (aCSF) containing the following (in mM): $125 \mathrm{NaCl}$, $2.5 \mathrm{KCl}, 1.25 \mathrm{NaH}_{2} \mathrm{PO}_{4}, 1 \mathrm{MgCl}_{2}, 2 \mathrm{CaCl}_{2}, 26$ $\mathrm{NaHCO}_{3}$ and $25 \mathrm{D}$-glucose, bubbled with $95 \% \mathrm{O}_{2} / 5 \% \mathrm{CO}_{2}$. After recovery for $30 \mathrm{~min}$ at $37^{\circ} \mathrm{C}$, slices were placed in a submerged chamber that was perfused at $2 \mathrm{ml} / \mathrm{min}$ with aCSF supplemented with $10 \mu \mathrm{M}$ GABAzine to block $\mathrm{GABA}_{\mathrm{A}}$ receptors. Recording electrodes $(3-5 \mathrm{M} \Omega$ ) were filled with a solution containing the following (in $\mathrm{mM}$ ): $120 \mathrm{~K}$ gluconate, $9 \mathrm{KCl}, 3.5$ $\mathrm{MgCl}_{2}, 4 \mathrm{NaCl}, 4 \mathrm{Na}_{2} \mathrm{ATP}, 0.4 \mathrm{Na}_{3} \mathrm{GTP}, 10$ HEPES, and 17.5 sucrose ( $\mathrm{pH} 7.2$ was adjusted with $\mathrm{KOH}$ and $300 \mathrm{Osm}$ ). All drugs were from Sigma and Tocris Bioscience, with the exception of fatty-acid amide hydrolase (FAAH) and monoacylglycerol lipase (MAGL) from Cayman Chemical. When chemicals were supplemented in the internal saline, the concentration of $\mathrm{K}$ gluconate was reduced accordingly to maintain the desired osmolarity (Vapro Osmometer 5520, Wescor).

Electrophysiology. Electrophysiological experiments were as in our previous work (Su and Shen, 2009; Su et al., 2010; Sun et al., 2011; Wang et al., 2012). PCs were visualized under an upright microscope (BX51; Olympus Optical) with a $40 \times$ water-immersion objective and equipped with infrared differential interference contrast enhancement. Whole-cell recordings were obtained with an Axon MultiClamp 700B amplifier (Molecular Devices). Currents were digitized at $10 \mathrm{kHz}$ and filtered at 3 $\mathrm{kHz}$. For PF stimulation, standard patch pipettes were filled with aCSF and placed in the middle third of the molecular layer. Synaptic responses were evoked every $20 \mathrm{~s}(0.05 \mathrm{~Hz})$ using $\sim 10 \mu \mathrm{A}$ pulses (100 $\mu$ s duration). The series resistance for whole-cell recordings was typically 7-10 $\mathrm{M} \Omega$
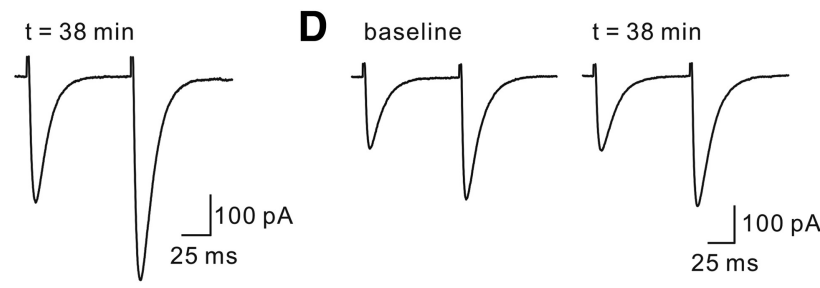

E

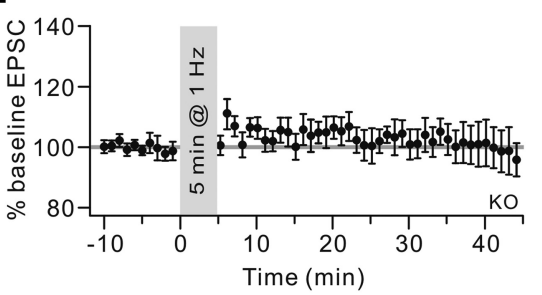

$\mathbf{F}$

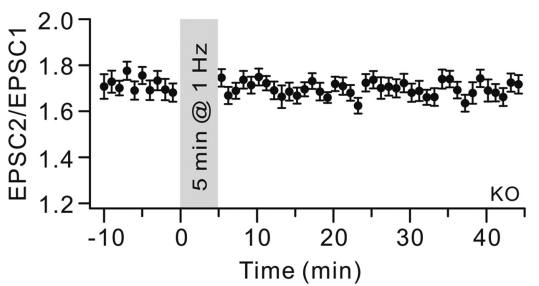

H

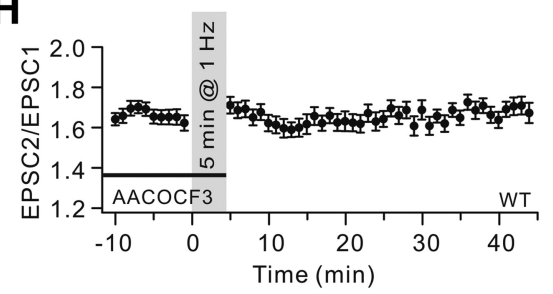

Figure 1. The $1 \mathrm{~Hz}$ PF-LTP is deficient in $\mathrm{CPLA}_{2} \alpha \mathrm{KO}$ mice. $A$, PF-LTP was induced by PF stimulation at $1 \mathrm{~Hz}$ for 5 min. Example (baseline) and after ( $t=38 \mathrm{~min}$ ) stimulation. EPSC amplitude was unaltered by the stimulation. $\boldsymbol{E}$, Time course of

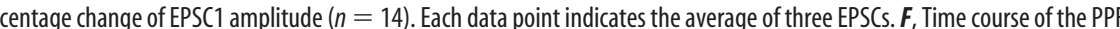
(in cells shown in $E$. G, Time course of percentage change of EPSC1 amplitude when WT cells were locally perfused with 100 $\mu \mathrm{M}$ AACOCF3 before and during stimulation $(n=11)$, indicating that AACOCF3 blocked the LTP induction $(n=11)$. $\boldsymbol{H}$, Time course of the PPF ratio of EPSCs from cells shown in $\boldsymbol{G}$.

after $70 \%$ compensation and monitored throughout. Recordings were excluded from analysis if series resistance, input resistance, or holding current varied by $>15 \%$ over the course of an experiment. To minimize the spontaneous spike activity that might escape voltage-clamp resulting from the poor space-clamp characteristics of PCs, baseline EPSC amplitude (holding potential $-70 \mathrm{mV}$ ) was kept relatively small (typically $<400 \mathrm{pA}$ ). All electrophysiological experiments were done at room temperature.

Granule cell culture. Dissociated cultures of cerebellar granule cells were made as previously described with some modifications (Gallo et al., 1982; He et al., 2010). Briefly, the cerebellar cortex was dissected on ice from anesthetized P0-P1 Sprague Dawley rats, digested with $0.1 \%$ trypsin for $7-9$ min at $37^{\circ} \mathrm{C}$, and dissociated into single cells by gentle trituration. Cells were plated on coverslips coated with 100 $\mathrm{g} / \mathrm{ml}$ poly-D-lysine in Neurobasal medium (Invitrogen) supplemented with 10\% FBS and 2\% B27 (Invitrogen). Cells were grown in basal modified Eagle's medium containing 10\% heat-inactivated FCS, gentamycin $(100 \mu \mathrm{g} / \mathrm{ml})$, and $5 \mathrm{~mm} \mathrm{KCl}$. The culture dishes were incubated at $37^{\circ} \mathrm{C}$ in humidified $95 \% \mathrm{O}_{2} / 5 \% \mathrm{CO}_{2}$. After $18-20 \mathrm{~h}, 10$ $\mu \mathrm{M}$ cytosine arabinoside was added to the medium to prevent the replication of non-neuronal cells. The culture medium was renewed at DIV2 and DIV5. 


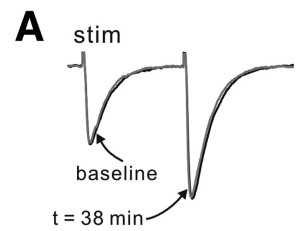

B
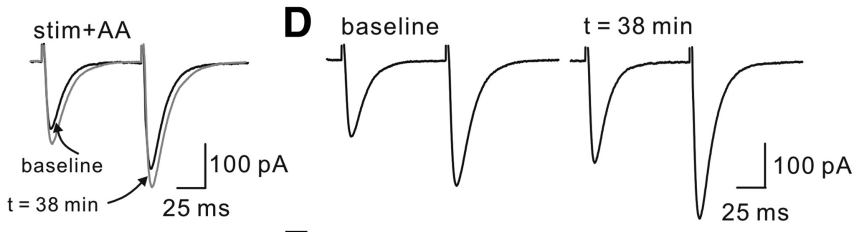

E
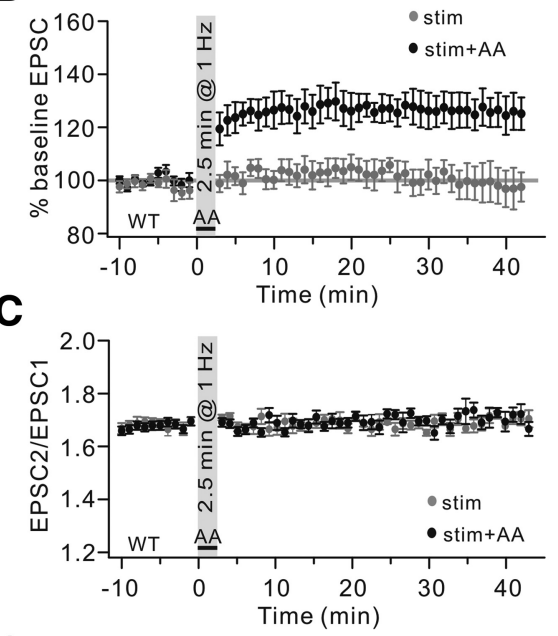

G

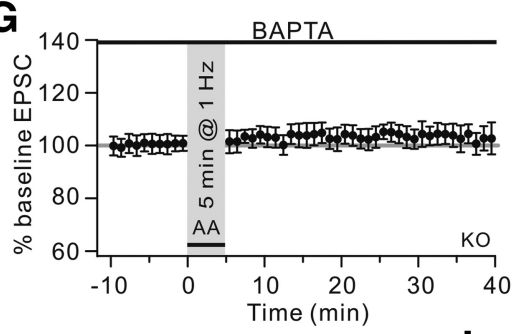

$\mathbf{F}$
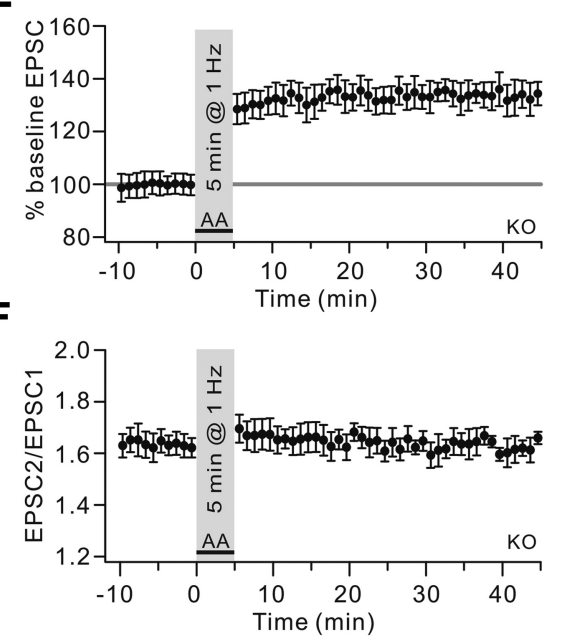

H

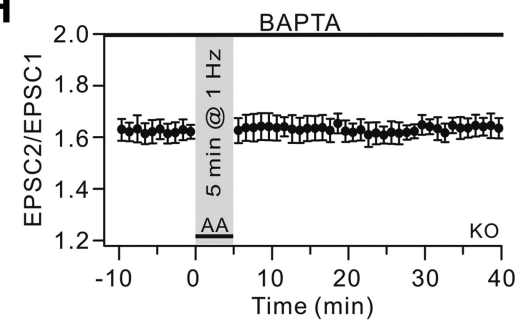

I

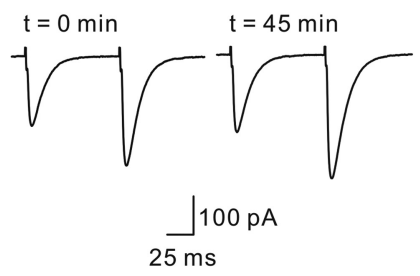

J

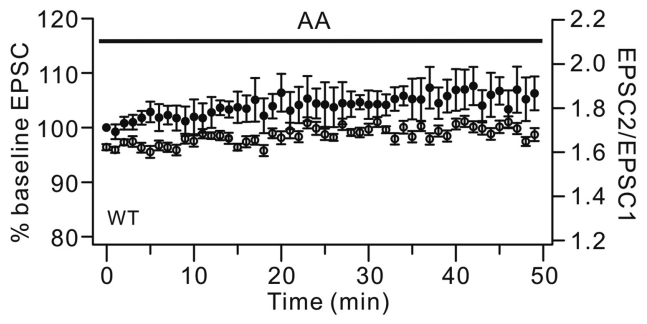

Figure 2. AA is involved in PF-LTP. A, Example PF-EPSCs from WT cells stimulated for $2.5 \mathrm{~min}$ at $1 \mathrm{~Hz}$ (stim) or locally perfused with $2 \mu \mathrm{m}$ AA overlapping the $1 \mathrm{~Hz}$ stimulation (stim $+\mathrm{AA}$ ). Black and gray traces represent EPSCs before (baseline) and after ( $t=$ $38 \mathrm{~min}$ ) the stimulation, respectively. EPSCs were potentiated in the stim + AA group but not in the stim group. $\boldsymbol{B}$, Time course of percentage changes of EPSC amplitudes in "stim" and "stim + AA" groups. Each data point indicates the average of three EPSCs. $\boldsymbol{C}$ Time course of the PPF ratio from cells shown in $\boldsymbol{B}$. D, KO cells were locally perfused with $2 \mu \mathrm{m}$ AA overlapping the $1 \mathrm{~Hz}$ stimulation for $5 \mathrm{~min}$. Example PF-EPSCs before (baseline) and after $(t=38 \mathrm{~min}$ ) stimulation are shown. $\boldsymbol{E}$, Time course of percentage change of EPSC amplitude. Each data point indicates the average of three EPSCs. $\boldsymbol{F}$, Time course of PPF ratio from cells shown in $\boldsymbol{E}$. $\boldsymbol{G}$, Time course of percentage change of PF-EPSC amplitude when $\mathrm{KO}$ cells were locally perfused with $2 \mu \mathrm{m}$ AA overlapping $1 \mathrm{~Hz}$ stimulation for $5 \mathrm{~min}$. These cells were internally perfused with $10 \mathrm{~mm}$ BAPTA. The mean EPSC amplitude at $38 \mathrm{~min}$ was $100 \pm 4 \%$ of baseline $(n=9) . p>0.05$ compared with baseline. $\boldsymbol{H}$, Time course of PPF ratio of EPSCs from cells shown in $\boldsymbol{G}$. $\boldsymbol{I}$, Example EPSCs at 0 and 45 min when WT cells were perfused with $2 \mu \mathrm{m}$ AA. J, Time courses of percentage change of EPSC amplitude (filled circles) and PPF ratio (open circles). Black bar represents the presence of $A A$.

NOS activity assay. The activity of NOS was quantified as the nitrite concentration in granule cell cultures according to the well-described Griess reaction. In brief, supernatant $(100 \mathrm{ml})$ from the control or WIN55,212-2 (WIN55)-treated group was used to measure the nitrite concentration according to the manufacturer's instructions (Jian Cheng Bioengineering). The Griess reagent contained 1\% sulfanilamide in 5\% phosphoric acid and $0.1 \%$ naphthylethylenediamine dihydrochloride in water. The absorbance of the mixture at $550 \mathrm{~nm}$ was determined with an ELISA plate reader (Dynatech Labs). All measurements of NOS activity were normalized for total protein content using a BCA protein assay kit (Pierce).

NO detection. NO efflux was monitored using an NO-selective amperometric microprobe (WPI), similar to previous work (Stefano et al., 1995). An L-shaped microprobe with a tip diameter of $30 \mu \mathrm{m}$ was used in cultured granule cells, and another straight sharp microprobe with a tip diameter of $7 \mu \mathrm{m}$ was used in cerebellar slices. The redox current was continuously recorded by a current-voltage converter circuit with DUO 18 software (WPI). Calibration of the electrochemical sensor was performed using different concentrations of the nitrosothiol donor S-nitroso- $N$-acetylDL-penicillamine to generate a standard curve. The probes were routinely cleaned in $0.1 \mathrm{M} \mathrm{H}_{2} \mathrm{SO}_{4}$ to remove the cellular debris that tended to accumulate. For NO recording in cultured cells, a micromanipulator attached to the stage of an inverted microscope (Olympus) was used to position the L-shaped microprobe 10 $\mu \mathrm{m}$ above the cell surface (see Fig. $5 C$ ). To record the intercellular NO in slices, a sharp microprobe was positioned $5 \mu \mathrm{m}$ away from the tip of the stimulating electrode using a fine micromanipulator (see Fig. $5 E$ ). Both probes were allowed to equilibrate for $40 \mathrm{~min}$ in the incubation medium before being transferred to cultures or tissues. Manipulation of tissues was performed only with glass instruments.

Statistics. Data analysis was performed using Excel 2003 (Microsoft), Clampfit 10 (Molecular Devices), and Igor Pro 6.0 (Wavemetrics). Error bars indicate the mean \pm SEM. $p$ values were determined by Student's $t$ test. The accepted level of significance was $p<0.05$. $n$ represents the number of cells or cultures tested.

\section{Results}

The $1 \mathrm{~Hz}$ PF-LTP is $\mathrm{CPLA}_{2} \alpha$-dependent Whole-cell patch-clamp recordings were made from mouse PCs to investigate the induction of $1 \mathrm{~Hz}$ PF-LTP according to the protocol described previously (LevRam et al., 2002; Coesmans et al., 2004; Belmeguenai and Hansel, 2005). In brief, PF-EPSCs were monitored in voltageclamp mode, and LTP was obtained when the PF was stimulated at $1 \mathrm{~Hz}$ for $5 \mathrm{~min}$ in current-clamp mode (Fig. 1A). The amplitude of LTP varies among laboratories (Lev-Ram et al., 2002; Belmeguenai and Hansel, 2005). In our hands, the potentiation of EPSCs recorded from wild-type (WT) mice reached $142 \pm 3 \%$ of baseline ( $t=38$ min; $n=20, p<0.01$ compared with baseline; Fig. $1 B$ ). The paired-pulse facilitation (PPF) ratio was measured by applying two pulses at an interval of $80 \mathrm{~ms}$, and it was unaltered by $1 \mathrm{~Hz}$ stimulation $(t=38$ min: $1.67 \pm 0.06 ; p>0.05$ compared with baseline, $1.66 \pm 0.02$; $n=20$; Fig. $1 C$ ), indicating that the presynaptic release was not affected (Lev-Ram et al., 2002; Coesmans et al., 2004; Belmeguenai and Hansel, 2005). $\mathrm{CPLA}_{2} \alpha$ is highly sensitive to $\mathrm{Ca}^{2+}$ and moves to the membrane when activated (Evans and Leslie, 2004). The same protocol for LTP induction was then performed in 
cPLA $_{2} \alpha \mathrm{KO}$ mice. Interestingly, $1 \mathrm{~Hz}$ LTP was blocked in $\mathrm{KO}$ cells (Fig. $1 D, E$ ) with PPF ratios unaffected (Fig. $1 F$ ). For comparison, WT cells were pretreated with a specific $\mathrm{CPLA}_{2} \alpha$ inhibitor, arachidonyl trifluoromethyl ketone (AACOCF3, 10 $\mu \mathrm{M})$, which significantly reduced the LTP (Fig. $1 G$ ). Likewise, the PPF ratios did not change after induction (Fig. $1 H)$. These results suggested that $1 \mathrm{~Hz}$ PFLTP is $\mathrm{CPLA}_{2} \alpha$-dependent.

\section{$\mathrm{cPLA}_{2} \alpha$ contributes to PF-LTP by providing $\mathrm{AA}$}

Because $\mathrm{CPLA}_{2} \alpha$ selectively liberates AA (Evans and Leslie, 2004), the effect of exogenous AA was tested in PF-LTP. We first asked whether AA is able to rescue PF-LTP in the weaker stimulation. Consistent with previous work (Lev-Ram et al., 2002), $1 \mathrm{~Hz}$ stimulation for $2.5 \mathrm{~min}$ (150 spikes) failed to induce PF-LTP (Fig. $2 A, B ; 99 \pm 8 \%$ at $t=38 \mathrm{~min} ; n=12, p>$ 0.05 compared with baseline). In contrast, local application of $2 \mu \mathrm{M}$ AA overlapping this weaker stimulation in WT cells was sufficient to potentiate PF-EPSCs (Fig. $2 A, B ; 126 \pm 5 \%$ of baseline at $t=38 \mathrm{~min}$; $n=13, p<0.01$ compared with baseline). Neither weak stimulation nor conjunction changed the PPF ratio (Fig. 2C). The next experiment was to apply exogenous AA $(2 \mu \mathrm{M})$ to $\mathrm{KO}$ cells simultaneously with the strong stimulation. As expected, local AA perfusion $(2 \mu \mathrm{M})$ overlapping 5 min stimulation robustly rescued the LTP in KO cells (Fig. 2D, $E ; 134 \pm 5 \%$ of baseline at $t=38 \mathrm{~min} ; n=$ $14, p<0.01$ compared with baseline). These results supported the view that AA is involved in $1 \mathrm{~Hz}$ PF-LTP induction. Alternatively, $\mathrm{CPLA}_{2} \alpha$ activated by the stimulation subsequently releases $\mathrm{AA}$ and contributes to LTP induction.

It has been shown that internal $\mathrm{Ca}^{2+}$ is increased by $1 \mathrm{~Hz}$ stimulation and is involved in the induction of PF-LTP (Coesmans et al., 2004). We next investigated whether the activation of $\mathrm{CPLA}_{2} \alpha / \mathrm{AA}$ signaling is sufficient to induce PF-LTP in a manner independent of internal $\mathrm{Ca}^{2+}$. To do so, BAPTA $(10 \mathrm{~mm})$, at a concentration lower than previously used (Coesmans et al., 2004), was added to the internal saline. We found that BAPTA completely blocked LTP in KO cells, even if these cells were given a conjunction of $2 \mu \mathrm{M}$ AA and PF stimulation (Fig. $2 G, H$ ). AA was also applied alone to test whether it is sufficient to potentiate PF-EPSCs. Against this assumption, we found that bath application of $2 \mu \mathrm{M}$ AA in WT cells did not induce an appreciable LTPlike potentiation of PF-EPSCs (Fig. 2I,J; $106 \pm 3 \%$ at $t=45 \mathrm{~min}$; $n=10, p>0.05$ compared with $t=1 \mathrm{~min}$ ). The PPF ratio also did not change during the AA application (Fig. $2 J$ ). Together, these results suggested that $\mathrm{CPLA}_{2} \alpha / \mathrm{AA}$ signaling is necessary but not sufficient for the induction of $1 \mathrm{~Hz}$ LTP. $\mathrm{Ca}^{2+}$ is the critical regulator of this LTP through regulating not only $\mathrm{CPLA}_{2} \alpha$ but other events, such as the phosphorylation of AMPARs. Notably, the effects of AA on PF-EPSC amplitude may be dose-dependent because higher concentrations of AA decrease PF-EPSC ampli- tude (Le et al., 2010; Wang et al., 2012), whereas lower concentrations have no effect (Le et al., 2010) (Fig. 2I).

\section{2-Arachidonoylglycerol/cannabinoid receptor 1 signaling is required for $1 \mathrm{~Hz}$ PF-LTP}

Endocannabinoids, $\mathrm{N}$ - arachidonoylethanolamine (AEA) and 2-arachidonoylglycerol (2-AG), are derivatives of AA (MalcherLopes et al., 2008). AEA is selectively hydrolyzed by FAAH (Cravatt et al., 2001; Okamoto et al., 2004) and 2-AG is selectively hydrolyzed by MAGL (Dinh et al., 2002; Bisogno et al., 2003). To determine the downstream effector of $\mathrm{CPLA}_{2} \alpha / \mathrm{AA}$ signaling in 1 Hz LTP, $0.7 \mu \mathrm{g} / \mathrm{ml}$ MAGL or $1 \mu \mathrm{g} / \mathrm{ml} \mathrm{FAAH} \mathrm{was} \mathrm{added} \mathrm{to} \mathrm{the}$ pipette solution and $1 \mathrm{~Hz}$ LTP was induced in WT cells. We found that $1 \mathrm{~Hz}$ LTP was blocked by MAGL (Fig. $3 A$ ). On the contrary, FAAH did not affect the LTP induction (Fig. $3 A$ ). The mean amplitudes of EPSCs at 38 min were $97 \pm 5 \%$ (MAGL; $n=13$, $p>0.05$ compared with baseline) and $138 \pm 6 \%(\mathrm{FAAH} ; n=14$, $p<0.01$ compared with baseline) (Fig. 3B). The PPF ratio was not affected in either condition (Fig. 3C). These results indicated that 2-AG, but not AEA, is required for LTP induction. CB1R, the receptor for endogenous 2-AG, mainly occurs at PF terminals (Diana et al., 2002). Thus, we investigated the role of CB1Rs in PF-LTP. AM251 (5 $\mu \mathrm{M})$, a CB1R antagonist, was locally applied to cells before and during stimulation. We found that PF-LTP was blocked by AM251 (Fig. 3D,E). Therefore, 2-AG and CB1R are needed for $1 \mathrm{~Hz}$ PF-LTP. 

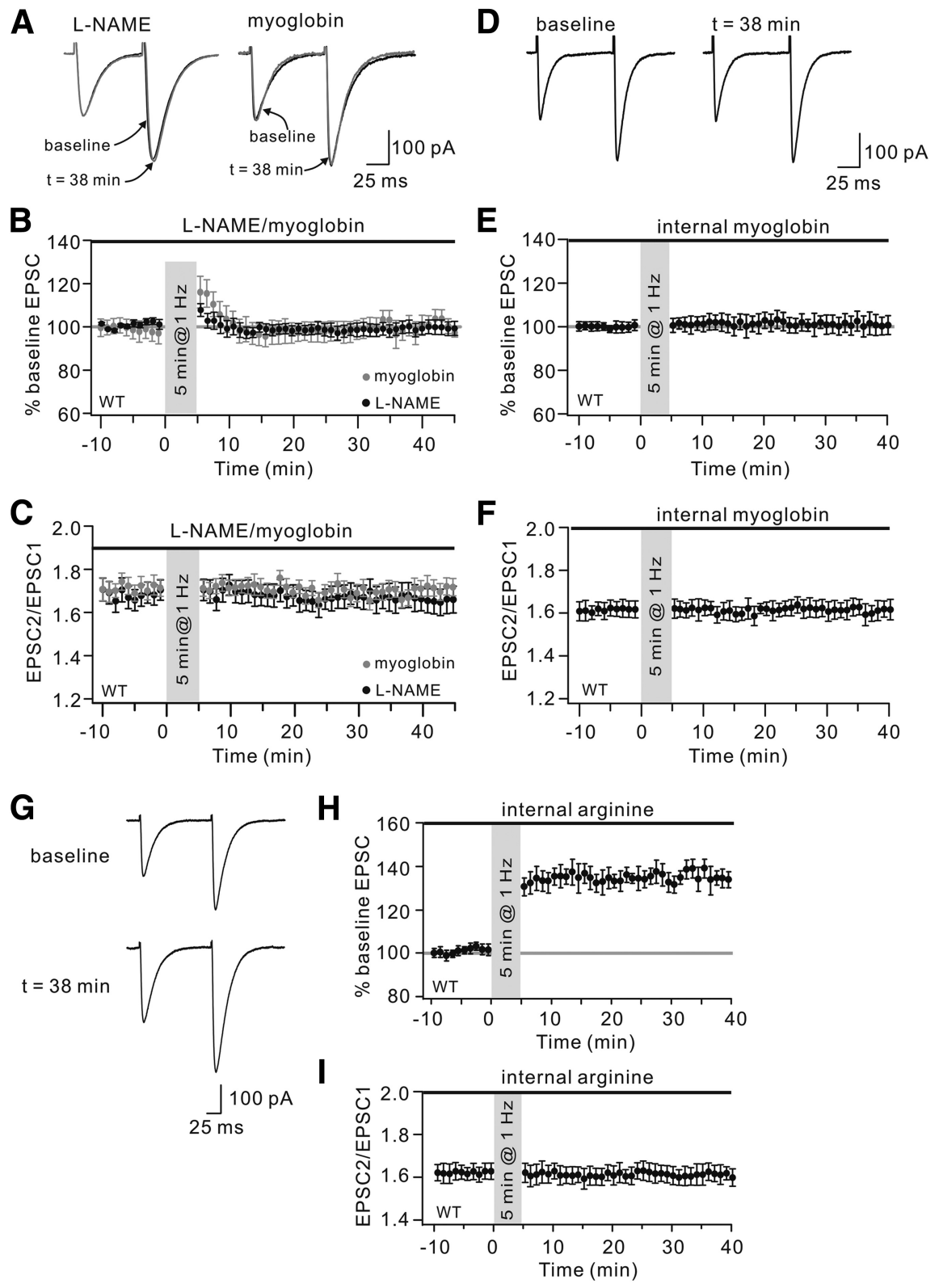

Figure 4. NO is required for PF-LTP. A, LTP induction in WT cells perfused with L-NAME or oxymyoglobin (myoglobin) in the bath. Both groups were stimulated for $5 \mathrm{~min}$ at $1 \mathrm{~Hz}$. Black and gray traces represent EPSCs before (baseline) and after ( $t=38 \mathrm{~min}$ ) stimulation, respectively. $\boldsymbol{B}$, Time course of percentage change of EPSCS in L-NAME and oxymyoglobin groups. Each data point indicates the average of three consecutive EPSCS. Black bars represent the duration of application of L-NAME and myoglobin. $C$, Time course of PPF ratio from cells shown in $\boldsymbol{B}$. $\boldsymbol{D}$, The $1 \mathrm{~Hz}$ LTP was blocked by the inclusion of oxymyoglobin inside PCs. Representative traces show EPSCs before (baseline) and after $(t=38 \mathrm{~min})$ stimulation. $\boldsymbol{E}$, Time course of percentage change of EPSCS with internal oxymyoglobin $(n=10)$. The mean EPSC amplitude at 38 min was $100 \pm 5 \%$ of baseline $(n=13) . p>0.05$ compared with baseline. Each data point indicates the average of three consecutive EPSCS. The bar above represents the inclusion of oxymyoglobin in PCs (internal myoglobin). $\boldsymbol{F}$, Time course of PPF ratio from cells shown in $\boldsymbol{E}$. $\boldsymbol{G}$, Example traces show EPSCs before (baseline) and after $(t=38 \mathrm{~min})$ stimulation. The $1 \mathrm{~Hz}$ LTP was normal when $5 \mu$ m arginine was included in the recording pipettes. $\boldsymbol{H}$, Time course of percentage change of EPSCs with internal arginine $(n=9)$. The mean EPSC amplitude at 38 min was $134 \pm 3 \%$ of baseline $(n=13)$. $p<0.01$ compared with baseline. Each data point indicates the average of three consecutive EPSCs. Bar indicates the duration of arginine included in PCs (internal arginine). $\boldsymbol{I}$, Time course of PPF ratio from cells shown in $\boldsymbol{H}$.

\section{Production and anterograde diffusion of NO are required for PF-LTP}

It is suggested that endogenous $\mathrm{NO}$ is necessary for the induction of both forms of synaptic plasticity at PF-PC synapses (Lev-Ram et al., 1995, 1997, 2002; Safo and Regehr, 2005). In the current work, several experiments were performed to assess the necessity of NO for the induction of $1 \mathrm{~Hz}$ LTP. First, slices were incubated with a competitive inhibitor of NOS, L-NAME $(100 \mu \mathrm{M})$, for $1 \mathrm{~h}$ before recordings. PCs were then stimulated in the continued presence of L-NAME. Our results demonstrated that $1 \mathrm{~Hz}$ LTP was blocked by L-NAME, showing that the average EPSC amplitude at 38 min was $100 \pm 3 \%$ of baseline (Fig. $4 A, B$, black traces; $n=$ $12, p>0.05$ compared with baseline), similar to previous work (Lev-Ram et al., 2002). Second, whether NO has to cross the intercellular space at PF-PC synapses in LTP was tested using oxymyoglobin, a high-affinity NO trap. Oxymyoglobin $(10 \mu \mathrm{M})$ was locally added to the cells throughout experiments with the duration longer than previous work (Lev-Ram et al., 2002). After the $1 \mathrm{~Hz}$ stimulation for 5 min, EPSCs transiently increased but immediately declined back to baseline (Fig. $4 A, B$, gray traces). The mean amplitude of EPSCs at 38 min was $101 \pm 5 \%$ of baseline ( $n=13, p>0.05$ compared with baseline).

Because oxymyoglobin is membraneimpermeable, these results implied that the diffusion of NO in the intercellular space is important for LTP. We next considered whether the target of $\mathrm{NO}$ action is inside the PC. If so, one would predict that intracellular oxymyoglobin should prevent the induction of LTP because of its membrane impermeability. To trap NO and inhibit its mediated activation of guanylate cyclase in PCs, $100 \mu \mathrm{M}$ oxymyoglobin was included in the patch pipettes. As predicted, $1 \mathrm{~Hz} \mathrm{LTP}$ was blocked by the inclusion of oxymyoglobin in PCs (Fig. $4 D, E)$, confirming that the target of $\mathrm{NO}$ is within the PC. Meanwhile, the PPF ratio was not affected after LTP induction (Fig. $4 F)$. To further identify the source of $\mathrm{NO}$ in LTP induction, an NOS inhibitor, $\mathrm{N}^{\mathrm{G}}$ nitro-arginine (arginine), was applied intracellularly in PCs. Arginine is a zwitterion and does not passively leak out of clamped cells to influence neighboring cells (Lev-Ram et al., 1995). Because arginine blocks NOS with an $\mathrm{IC}_{50}$ of $\leq 1 \mu \mathrm{M}$ (East and Garthwaite, 1990; Dwyer et al., 1991; Furfine et al., 1993), $5 \mu \mathrm{M}$ arginine was included in the patch pipettes to block NOS. Under these conditions, $1 \mathrm{~Hz} \mathrm{PF}$ stimulation induced LTP normally (Fig. $4 G, H)$, suggesting that such LTP does not need NOS activity within the PC.

\section{Activation of CB1Rs at $\mathrm{PF}$ terminals produces NO}

To date, the effector molecules of CB1Rs in brain are not clear. The experiments above gave an interesting clue that CB1R activation may cause the production of $\mathrm{NO}$ in granule cells and PF terminals. Several experiments were performed to investigate whether this speculation is correct. First, NOS activity in cultured 
granule cells (Fig. 5A) was measured in the absence and presence of the CB1R agonist, WIN55 ( $5 \mu \mathrm{M})$ using an ELISA plate reader to assess nitrite concentration. Our results showed that NOS activity increased significantly upon WIN55 application in a time-dependent manner (Fig. $5 B$ ), indicating that the activation of CB1Rs increases NOS activity in granule cells. Second, NO efflux in cell cultures was measured using an L-shaped NO electrode placed close to the surface of the cells (Fig. 5C). Continuous monitoring with the NO electrode showed no detectable NO efflux (nanomolar level) at baseline (Fig. 5D). After the cells had stabilized for at least $150 \mathrm{~s}, 5 \mu \mathrm{M}$ WIN55 was locally administered. This puff of WIN55 significantly increased NO efflux in a transient and reproducible manner (Fig. 5D; WIN55, $30 \pm 5 \mathrm{nM} ; n=7, p<0.01$ compared with control). This result was consistent with the NOS assay experiment, but much more efficient in detecting activity of the NOS/NO cascade. Coapplication of $5 \mu \mathrm{M}$ AM251 with $5 \mu \mathrm{M}$ WIN55 almost completely blocked the NO efflux (Fig. 5D; WIN55+AM251, $1.1 \pm 0.9 \mathrm{nM}$; $n=6, p<0.01$ compared with the WIN55 group). These experiments demonstrated that CB1R activation of granule cells causes NO production and efflux.

To assess the role of CB1R in NO production at PF terminals, a sharp NO electrode was placed near the stimulation pipette in cerebellar slices (Fig. 5E), and then $1 \mathrm{~Hz}$ LTP and the intercellular efflux of NO were simultaneously recorded at PF-PC synapses. We found that $1 \mathrm{~Hz} \mathrm{PF}$ stimulation for 5 min increased the concentration of intercellular $\mathrm{NO}$, which reached a peak during the stimulation and slowly decreased as time elapsed (Fig. $5 F$; peak: $4.2 \pm 0.5 \mathrm{~nm} ; n=10, p<0.01 \mathrm{com}-$

pared with control). Coapplication of AM251 ( $5 \mu \mathrm{M})$ during $1 \mathrm{~Hz}$ stimulation significantly reduced the concentration of intercellular NO (Fig. 5F; peak: $0.4 \pm 0.2 \mathrm{~nm} ; n=7$ ). Therefore, these results showed that $\mathrm{CB} 1 \mathrm{R}$ activation induces $\mathrm{NO}$ production and efflux at PF terminals.

\section{NMDAR-induced NO release from stellate cells is not involved in $1 \mathrm{~Hz}$ LTP}

NO is widely distributed in neurons (Bredt and Snyder, 1992; Dawson et al., 1992). In the cerebellum, previous work demonstrated that NMDARs activate nNOS/NO signaling and play important roles in PF-LTD induced by strong PF stimulation (Casado et al., 2002). Convincing evidence from Shin and Linden (2005) showed that this NMDAR/NO cascade is localized to interneurons rather than PFs. Because PF stimulation excites neighboring dendrites over a certain range, a critical question was whether $1 \mathrm{~Hz}$ PF stimulation also results in the activation of postsynaptic interneurons, which consequently leads to NO production. To answer this question, high-frequency $(100 \mathrm{~Hz})$ and
B
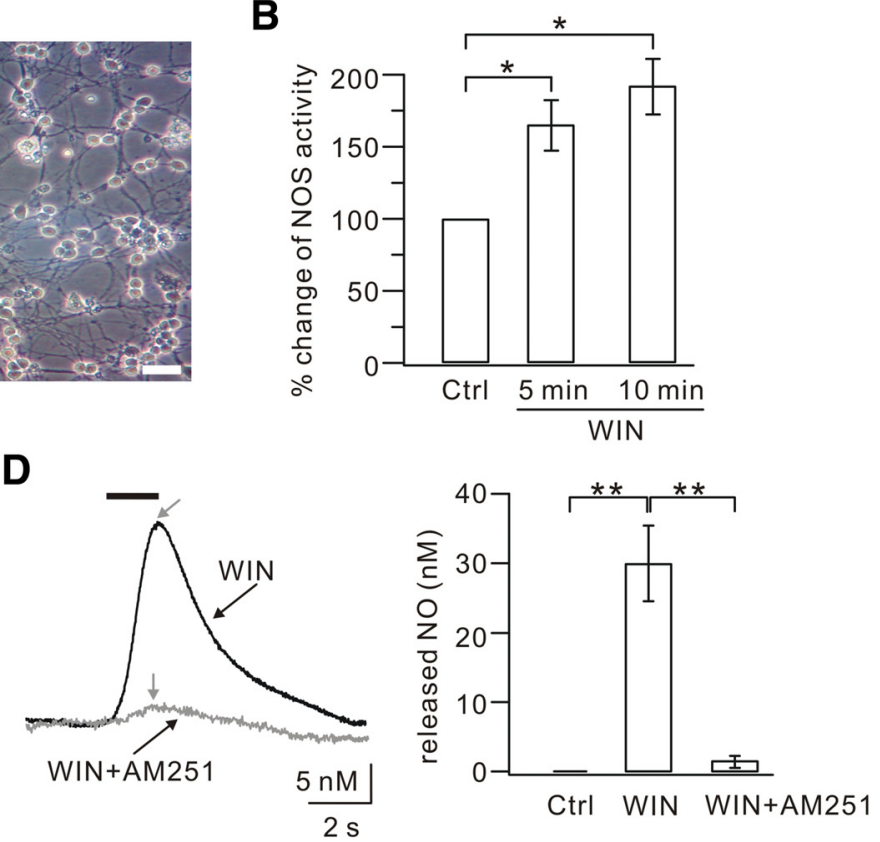

F $5 \min @ 1 \mathrm{~Hz}$
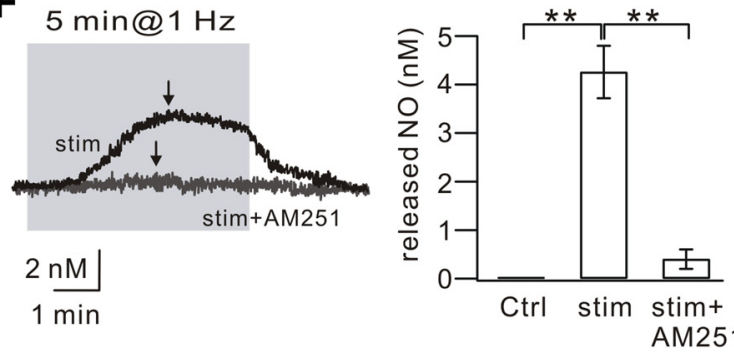

AM251

Figure 5. CB1R activation produces $\mathrm{NO}$ in granule cells and at PF terminals. A, DIC image of cultured cerebellar granule cells (DIV7). Scale bar, $10 \mu \mathrm{m}$. B, ELISA detection of NOS in cultured granule cells. The NOS activity was calculated as the concentration (th ed N0 electrode in cultured granule cells. Chemicals were locally applied onto cells as shown. D, Example traces of NO

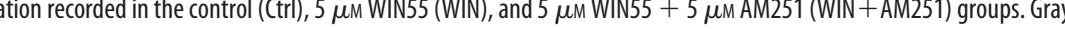
stimulation (stim) and $1 \mathrm{~Hz}$ stimulation $+5 \mu \mathrm{M}$ AM251 (stim + AM251). Black arrows indicate the peak of each response. Right bar graphs represent the averaged peak values. ${ }^{*} p<0.05$. ${ }^{* *} p<0.01$.

low-frequency $(1 \mathrm{~Hz})$ PF stimulation was applied to stellate cells (SCs) during whole-cell recordings (Fig. 6A). To record NMDA currents, SCs were clamped at $40 \mathrm{mV}$ and perfused with $\mathrm{Mg}^{2+}$. free aCSF supplemented with $50 \mu \mathrm{M}$ GYKI53655, a selective antagonist of AMPARs. Short (5 pulses) and long (60 pulses) trains of PF stimuli at $1 \mathrm{~Hz}$ were consecutively delivered to the same cell. As shown in Figure $6 B$, neither short nor long $1 \mathrm{~Hz}$ PF trains elicited NMDAR-mediated currents. Burst stimuli $(100 \mathrm{~Hz})$ were then applied to PFs, and NMDAR-mediated currents were induced after 5 pulses. Application of $50 \mu \mathrm{M}$ D-AP5 was sufficient to eliminate the outward current (Fig. 6C). Thus, NMDARmediated currents were only inducible by high-frequency PF stimulation.

To examine the distinct roles of high- and low-frequency PF stimulation on NO release, a sharp NO electrode was placed near the stimulation pipette in the molecular layer of cerebellar slices, whereas SCs were current-clamped (Fig. 6D). The voltage response of SCs and the intercellular NO concentration at PF-SC synapses were simultaneously recorded. We found that there was 


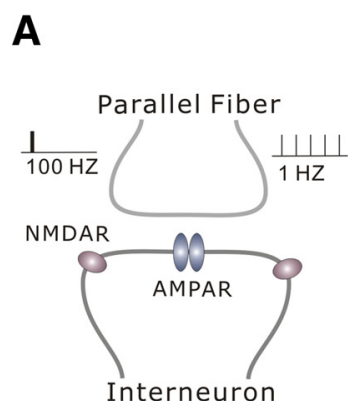

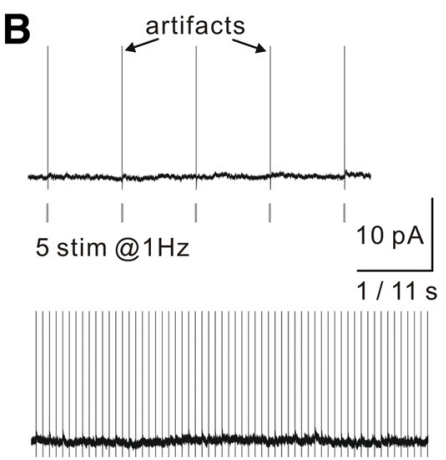

60 stim@1 @z

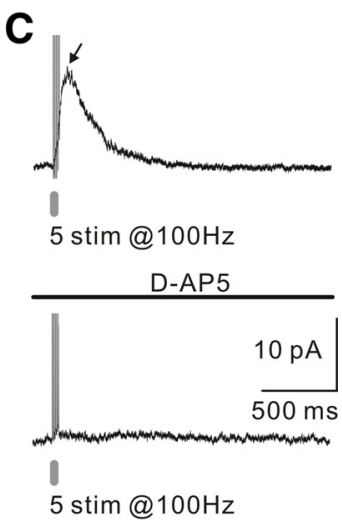

$\mathbf{F}$

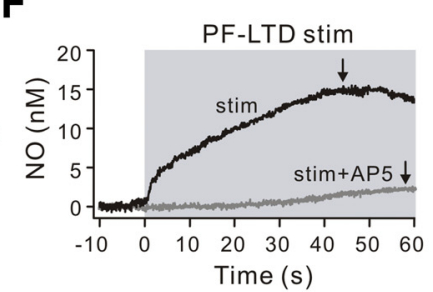

D

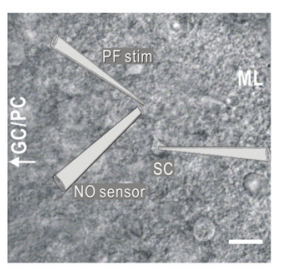

E

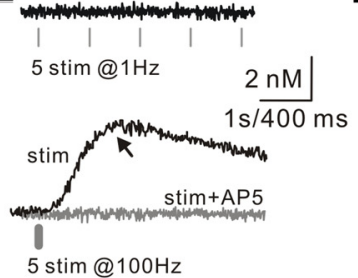

I

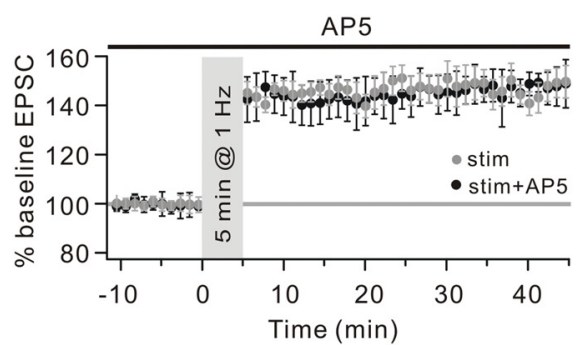

J

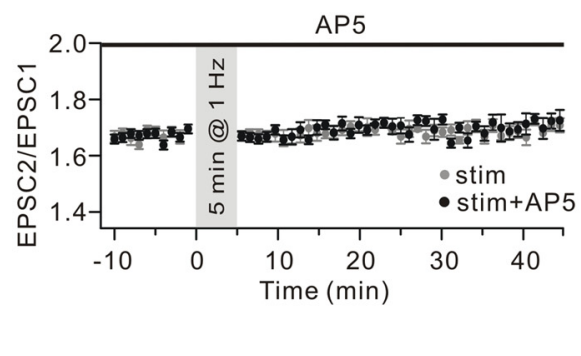

Figure 6. NMDAR-mediated NO release from SCS. $\boldsymbol{A}$, Schematic illustration showing the stimulation protocols at PF-SC synapses and the localization of postsynaptic AMPARs and NMDARs in SCs. PF stimulation (100 Hz or $1 \mathrm{~Hz}$ ) was applied at PF-SC synapses as high- and low-frequency stimuli, respectively. AMPARs are located in the center, whereas NMDARs are extrasynaptic. $\boldsymbol{B}$, Representative recordings from one $S C$ in response to 5 (top) and 60 (bottom) PF stimuli given at $1 \mathrm{~Hz}$. Cells were clamped at $40 \mathrm{mV}$ and perfused with GYKI53655 to block AMPAR responses. Time scales: top, $1 \mathrm{~s}$; bottom, $11 \mathrm{~s}$. C, Representative recordings from one SC in response to $5 \mathrm{PF}$ stimuli given at $100 \mathrm{~Hz}$. Cells were clamped at $40 \mathrm{mV}$ and perfused with GYKI53655 to block AMPAR-mediated responses. High-frequency stimulation induced an outward current, which was blocked by the application of $50 \mu \mathrm{M}$ D-AP5 (bottom). D, DIC image illustrating the recording configuration for NO release from one SC. Glass pipettes for PF stimulation and whole-cell recording in the SC as well as an NO electrode were placed on the slices as shown in the illustration. ML, Molecular layer; GC/PC, granule cells/Purkinje cells. Scale bar, $20 \mu \mathrm{m}$. $\boldsymbol{E}$, Examples of NO recording from one SC evoked by $1 \mathrm{~Hz}$ and $100 \mathrm{~Hz}$ PF stimulation. Slices were perfused with $\mathrm{Mg}^{2+}$-free aCSF containing GYKI53655. The responses for $1 \mathrm{~Hz}$ and $100 \mathrm{~Hz} \mathrm{PF}$ stimulation are shown in the top and bottom as labeled. Time scales: top, 1s; bottom, $400 \mathrm{~ms}$. The black arrow indicates the peak of N0 release. The gray trace in the bottom represents that $50 \mu \mathrm{m}$ D-AP5 blocked PF stimulation-induced N0 release. $\boldsymbol{F}$, Examples of N0 recording when PFs were given the induction for PF-LTD (PF-LTD stim). Slices were perfused with $\mathrm{Mg}^{2+}$-free aCSF containing GYKI53655. The shadowed background shows the duration of PF-LTD stimulation. The black and gray traces represent the N0 responses with PF-LTD stimulation and PF-LTD stimulation plus D-AP5 (stim + AP5), respectively, showing that D-AP5 blocked most of the NO release. The black arrows indicate the peak of N0 release in each condition. $\mathbf{G}$, Averaged peak values of N0 efflux under different stimulation conditions. Five pulses at $1 \mathrm{~Hz}(5 \mathrm{stim}$ at $1 \mathrm{~Hz}$ ): $0, n=12$. Single pulse at $100 \mathrm{~Hz}$ ( 5 stim at $100 \mathrm{~Hz}): 4.9 \pm 1.3 \mathrm{~nm}, n=$ 9. Single pulse at $100 \mathrm{~Hz}$ with D-AP5 ( 5 stim at $100 \mathrm{~Hz}+$ AP5): $0.3 \pm 0.2 \mathrm{~nm}, n=6$. PF-LTD stimulation (PF-LTD stim): $17.4 \pm 1.5$ $\mathrm{nm}, n=6$.PF-LTD stimulation with D-AP5 (PF-LTD stim + D-AP5): $2.3 \pm 0.5 \mathrm{~nm}, n=4$. For comparison, the released N0 in response to $5 \mathrm{~min}$ PF stimulation at $1 \mathrm{~Hz}$ shown in Figure $5 F$ is replotted ( 5 min at $1 \mathrm{~Hz}$, gray bar). ${ }^{*} p<0.05 .{ }^{* *} p<0.01 . \boldsymbol{H}$, Example traces of PF-EPSCs before (baseline) and after $(t=38 \mathrm{~min}) 1 \mathrm{~Hz}$ stimulation when slices were perfused with D-AP5. no detectable NO release in response to 5 stimuli at $1 \mathrm{~Hz}$ (Fig. 6E). On the contrary, 5 pulses at $100 \mathrm{~Hz}$ evoked a prominent NO release, which was eliminated by 50 $\mu \mathrm{M}$ D-AP5 (Fig. $6 E$ ). These results suggested that high-frequency PF bursts are sufficient to evoke NMDAR-mediated NO release. Previous work demonstrated that the induction of PF-LTD requires 100 $\mathrm{Hz} \mathrm{PF}$ stimulation repeated 30 times at $2 \mathrm{~s}$ intervals (Shin and Linden, 2005; Steinberg et al., 2006). We used this to measure how much $\mathrm{NO}$ is released in response to PF-LTD induction. Thirty PF bursts at $100 \mathrm{~Hz}$ elicited a gradually increasing NO release (Fig. $6 F$ ), which had a peak amplitude much greater than that in response to $1 \mathrm{~Hz}$ PF stimulation for $1 \mathrm{~min}$ and 5 pulses at $100 \mathrm{~Hz}$. This NO release was almost blocked by $50 \mu \mathrm{M}$ D-AP5, suggesting that PF-LTD induction is sufficient to elicit a large NMDAR-mediated NO release. The remaining NO after D-AP5 treatment might have been caused by the activation of CB1Rs in PF terminals (Fig. $6 F, G$ ). It has been demonstrated that the pharmacological blockade of NMDARs and resulting NO release blocks PF-LTD (Casado et al., 2002; Shin and Linden, 2005). Thus, it was of interest to investigate whether $1 \mathrm{~Hz}$ PF-LTP also requires the activation of NMDARs. Cerebellar slices were perfused with aCSF supplemented with $50 \mu \mathrm{M}$ $\mathrm{D}-\mathrm{AP} 5$, and the $1 \mathrm{~Hz}$ LTP induction protocol was performed (Fig. 6H). Unlike PFLTD, $1 \mathrm{~Hz}$ LTP was normally induced by this stimulation (Fig. 6I). Together, these results showed that NO synthesis and release from SCs and PFs are the result of different mechanisms. Weak stimulation with a long duration evokes a small NO release from PFs, whereas strong PF stimulation evokes a large NO release from SCs.

\section{Discussion}

The main finding of this study is that the induction of $1 \mathrm{~Hz}$ PF-LTP requires concurrent presynaptic and postsynaptic events. Figure 7 summarizes the essential cascades involved in PF-LTP (red lines) and PF-LTD (black lines). The mechanisms for PF-LTD have been well defined. In brief, it is usually induced with strong $\mathrm{PF}$ stimulation or conjunctive $\mathrm{CF} / \mathrm{PF}$ stimulation (Hansel et al., 2001; Linden,

$\leftarrow$

$I$, Time course of percentage change of EPSC amplitude in response to 5 min stimulation at $1 \mathrm{~Hz}($ stim; $n=10)$ and the overlapping application of $50 \mu \mathrm{m} \mathrm{D}$-AP5 with $1 \mathrm{~Hz}$ stimulation (stim + AP5). Each data point indicates the average of three successive EPSCs evoked at $0.05 \mathrm{~Hz}$. J, PPF ratios from a subset of the cells shown in $I$. 
2003). The released glutamate acts upon postsynaptic mGluRs and AMPARs and results in a high $\mathrm{Ca}^{2+}$ threshold (Coesmans et al., 2004). After these initial signals, there is a requirement for the activation of PKC and $\alpha$ CaMKII (Hansel et al., 2001, 2006; Leitges et al., 2004). The $\mathrm{CPLA}_{2} \alpha / \mathrm{COX} 2$ cascade is critical for PFLTD by acting upstream of PKC (Le et al., 2010). The involvement of CB1R and NO/ soluble guanylyl cyclase/PKG/phosphatase pathways is also suggested (Hansel et al., 2001; Safo and Regehr, 2005). The required NO is mediated by NMDARs localized to interneurons (Lev-Ram et al., 1995, 1997; Casado et al., 2002; Shin and Linden, 2005) (Fig. 6). PF-LTD is expressed postsynaptically, as a reduction in the number of surface AMPARs (Wang and Linden, 2000; Xia et al., 2000). In contrast to PF-LTD, $1 \mathrm{~Hz}$ PF-LTP requires a low $\mathrm{Ca}^{2+}$ threshold (Coesmans et al., 2004), which subsequently leads to $\mathrm{cPLA}_{2} \alpha$ activation, AA liberation, and the production of 2-AG that binds to presynaptic CB1R (Figs. 1, 2, and 3). Activated $\mathrm{CB} 1 \mathrm{R}$ triggers NOS activation and produces a low level of $\mathrm{NO}$ from PF terminals (Figs. 4 and 5). NO anterogradely crosses the intercellular space and is assumed to target phosphatases and AMPAR trafficking. Interestingly, PFLTP shares several molecules with LTD, including $\mathrm{Ca}^{2+}, \mathrm{CPLA}_{2} \alpha$, $\mathrm{CB} 1 \mathrm{R}$, and NO (highlighted in Fig. 7). One notable bifurcation between PF-LTD and PF-LTP is mGluR. It is shown that mGluRs are required for PF-LTD expression by attributing $\mathrm{Ca}^{2+}$ (Takechi et al., 1998; Brasnjo and Otis, 2001; Belmeguenai et al., 2008). However, they do not affect cerebellar $1 \mathrm{~Hz}$ LTP (Belmeguenai et al., 2008).

2-AG is a retrograde messenger that mediates the induction of LTD in the hippocampus (Chevaleyre and Castillo, 2003) and cerebellum (Safo and Regehr, 2005). Diacylglycerol lipase (DAGL) is shown to be needed for the formation of 2-AG in cerebellar LTD (Safo and Regehr, 2005). The same paper also showed that blocking DAGL does not affect the 2-AG/CB1Rmediated depolarization-stimulated inhibition of excitation (DSE) (Safo and Regehr, 2005), suggesting that 2-AG may be synthesized through a pathway independent of DAGL. Consistent with this speculation, our previous work showed that $\mathrm{CPLA}_{2} \alpha / \mathrm{AA}$ signal produces 2-AG during DSE (Wang et al., 2012). This conclusion was further strengthened by the present work that 2-AG is the substrate of $\mathrm{CPLA}_{2} \alpha / \mathrm{AA}$ signaling in $1 \mathrm{~Hz}$ PF-LTP. Together, these data indicate that two independent pathways, phospholipase C (PLC)/DAGL and $\mathrm{CPLA}_{2} \alpha / \mathrm{AA}$, may both control the production of 2-AG.

DSE results from a brief depolarization of PCs (Kreitzer and Regehr, 2001). The stimulation strength for both DSE and $1 \mathrm{~Hz}$ PF-LTP is much weaker than that for LTD (Hartell, 1996; Ito, 2001; Kreitzer and Regehr, 2001; Shin and Linden, 2005; Steinberg et al., 2006). Thus, the internal $\mathrm{Ca}^{2+}$ evoked by which stimulation may be a decisive factor in PF-PC synaptic plasticity (Fig. 7). Because a prolonged elevation of $\mathrm{Ca}^{2+}$ is needed to activate PLC/DAGL signal (Maejima et al., 2005) and a lower level of $\mathrm{Ca}^{2+}$ activates $\mathrm{CPLA}_{2} \alpha$ (Evans and Leslie, 2004), it will be inter- esting to investigate how $\mathrm{Ca}^{2+}$ differentially modulates the activity of PLC/DAGL and $\mathrm{CPLA}_{2} \alpha / \mathrm{AA}$ signals, as well as their roles in $2-\mathrm{AG}$ production. In addition, the function of $\mathrm{CPLA}_{2} \alpha$ in PF-PC plasticity is complicated. Whereas we found that $\mathrm{CPLA}_{2} \alpha$ is required for $1 \mathrm{~Hz}$ LTP induction, Le et al. (2010) revealed a crucial role of the $\mathrm{CPLA}_{2} \alpha$-cyclooxygenase-2-PKC $\alpha$ cascade in PF-LTD evoked by a strong surge of intracellular $\mathrm{Ca}^{2+}$. Therefore, $\mathrm{cPLA}_{2} \alpha$ may also play a dual role in PF-PC plasticity, depending on how much it is activated (Fig. 7).

Although AEA and 2-AG are both localized in the hippocampus and cerebellum (Bisogno et al., 1999), 2-AG is the only retrograde messenger to mediate DSE, LTD, and LTP (Chevaleyre and Castillo, 2003; Safo and Regehr, 2005; Wang et al., 2012) (Fig. 3). AA metabolism is highly interactive among signaling pathways (Hoggatt and Pelus, 2010). Hence, it is necessary to examine the biosynthesis of AEA and 2-AG after PF stimulation to address why AEA is not the retrograde messenger. Another mystery is the distinct roles of CB1R at PF terminals, as it is required for both LTD and LTP (Fig. 7). It has been suggested that CB1R activation causes the reduced release of neurotransmitter by modulating the activity of ion channels and/or adenylyl cyclases (Levenes et al., 1998; Takahashi and Linden, 2000; Daniel et al., 2004), which may explain the inhibition of presynaptically expressed PF-LTP by CB1Rs (van Beugen et al., 2006) and the requirement of CB1Rs in PF-LTD (Safo and Regehr, 2005; van Beugen et al., 2006). However, the decrease of transmitter release does not account for our finding that CB1Rs stimulated NO production at PF terminals (Fig. 5). Thus, the mechanism underlying CB1R-NOS cascade remains to be explored.

Coesmans et al. (2004) showed that the induction of PF-LTD versus PF-LTP is governed by a $\mathrm{Ca}^{2+}$ threshold rule that operates inversely to the Bienenstock, Cooper, and Munro model (Bienenstock et al., 1982). PF-LTD has a higher $\mathrm{Ca}^{2+}$ threshold 
mainly contributed by climbing fibers (Coesmans et al., 2004). Here, we showed that $1 \mathrm{~Hz}$ PF stimulation evoked limited NO release from PF terminals (Fig. 5), but PF-LTD stimulation generated a large amount from interneurons (Fig. 6). Combined with previous work (Lev-Ram et al., 2002; Belmeguenai and Hansel, 2005; Shin and Linden, 2005; Schonewille et al., 2010), our results suggested that NO may act as another threshold in the weakening and strengthening of PF-PC synapses (Fig. 7). Interestingly, a strong but brief PF stimulation ( 8 pulses at $100 \mathrm{~Hz}$ ) can induce PF-LTP (Piochon et al., 2010). Consistently, we found that $5 \mathrm{PF}$ stimuli at $100 \mathrm{~Hz}$ induced a measurable $\mathrm{NO}$ rise (Fig. 6E). Together, these results highlight the importance of NO in LTP induction, that is, PF-LTP can be induced by an adequate amount of NO, no matter where it comes from. Nevertheless, NO differs from $\mathrm{Ca}^{2+}$ because it is regulated by CB1Rs at PF terminals during LTP (Fig. 5) and by extrasynaptic NMDARs on interneurons during LTD (Fig. 6). In contrast, the $\mathrm{Ca}^{2+}$ transients required for LTP and LTD induction reflect the excitable state of PCs (Coesmans et al., 2004).

PF-LTP depends on serine/threonine phosphatase activity (Belmeguenai and Hansel, 2005; Schonewille et al., 2010). PFLTD is PKC- and $\alpha$ CaMKII-dependent (Hansel et al., 2001; Ito, 2001; Hansel et al., 2006). Thus, $\mathrm{Ca}^{2+}$ may bidirectionally control the AMPAR trafficking in LTP and LTD through the kinase/ phosphatase switch because both kinase and phosphatase PP2B are sensitive to $\mathrm{Ca}^{2+}$ (Lisman, 1989). On the other hand, it is shown that NO activates soluble guanylyl cyclase and causes phosphatase inhibition of AMPARs in LTD (Shin and Linden, 2005). Nevertheless, how it modulates AMPARs in $1 \mathrm{~Hz}$ LTP remains obscure. Interestingly, NO-based S-nitrosylation of cysteine has been shown on G-proteins, transcription factors, transporters, transmitter receptors (Lei et al., 1992), and ion channels (Stamler et al., 1997; Yao et al., 1997). Moreover, NO-dependent $\mathrm{S}$-nitrosylation of $\mathrm{N}$-ethylmaleimide-sensitive factor promotes GluR2 insertion in cultured cortical neurons (Huang et al., 2005). Thus, whether and how the nitrosylation of $N$-ethylmaleimidesensitive factor and AMPAR trafficking are affected by NO or PF stimulation in the cerebellum need to be investigated.

\section{References}

Belmeguenai A, Hansel C (2005) A role for protein phosphatases 1,2A, and 2B in cerebellar long-term potentiation. J Neurosci 25:10768-10772. CrossRef Medline

Belmeguenai A, Botta P, Weber JT, Carta M, De Ruiter M, De Zeeuw CI, Valenzuela CF, Hansel C (2008) Alcohol impairs long-term depression at the cerebellar parallel fiber-Purkinje cell synapse. J Neurophysiol 100: 3167-3174. CrossRef Medline

Bienenstock EL, Cooper LN, Munro PW (1982) Theory for the development of neuron selectivity: orientation specificity and binocular interaction in visual cortex. J Neurosci 2:32-48. Medline

Bisogno T, Berrendero F, Ambrosino G, Cebeira M, Ramos JA, FernandezRuiz JJ, Di Marzo V (1999) Brain regional distribution of endocannabinoids: implications for their biosynthesis and biological function. Biochem Biophys Res Commun 256:377-380. CrossRef Medline

Bisogno T, Howell F, Williams G, Minassi A, Cascio MG, Ligresti A, Matias I, Schiano-Moriello A, Paul P, Williams EJ, Gangadharan U, Hobbs C, Di Marzo V, Doherty P (2003) Cloning of the first sn1-DAG lipases points to the spatial and temporal regulation of endocannabinoid signaling in the brain. J Cell Biol 163:463-468. CrossRef Medline

Boyden ES, Katoh A, Pyle JL, Chatila TA, Tsien RW, Raymond JL (2006) Selective engagement of plasticity mechanisms for motor memory storage. Neuron 51:823-834. CrossRef Medline

Brasnjo G, Otis TS (2001) Neuronal glutamate transporters control activation of postsynaptic metabotropic glutamate receptors and influence cerebellar long-term depression. Neuron 31:607-616. CrossRef Medline

Bredt DS, Snyder SH (1992) Nitric oxide, a novel neuronal messenger. Neuron 8:3-11. CrossRef Medline
Casado M, Isope P, Ascher P (2002) Involvement of presynaptic $N$-methylD-aspartate receptors in cerebellar long-term depression. Neuron 33:123130. CrossRef Medline

Chen C, Regehr WG (1997) The mechanism of cAMP-mediated enhancement at a cerebellar synapse. J Neurosci 17:8687-8694. Medline

Chevaleyre V, Castillo PE (2003) Heterosynaptic LTD of hippocampal GABAergic synapses: a novel role of endocannabinoids in regulating excitability. Neuron 38:461-472. CrossRef Medline

Coesmans M, Weber JT, De Zeeuw CI, Hansel C (2004) Bidirectional parallel fiber plasticity in the cerebellum under climbing fiber control. Neuron 44:691-700. CrossRef Medline

Cravatt BF, Demarest K, Patricelli MP, Bracey MH, Giang DK, Martin BR, Lichtman AH (2001) Supersensitivity to anandamide and enhanced endogenous cannabinoid signaling in mice lacking fatty acid amide hydrolase. Proc Natl Acad Sci U S A 98:9371-9376. CrossRef Medline

Daniel H, Rancillac A, Crepel F (2004) Mechanisms underlying cannabinoid inhibition of presynaptic $\mathrm{Ca}^{2+}$ influx at parallel fibre synapses of the rat cerebellum. J Physiol 557:159-174. CrossRef Medline

Dawson TM, Dawson VL, Snyder SH (1992) A novel neuronal messenger molecule in brain: the free radical, nitric oxide. Ann Neurol 32:297-311. CrossRef Medline

De Zeeuw CI, Hansel C, Bian F, Koekkoek SK, van Alphen AM, Linden DJ, Oberdick J (1998) Expression of a protein kinase C inhibitor in Purkinje cells blocks cerebellar LTD and adaptation of the vestibulo-ocular reflex. Neuron 20:495-508. CrossRef Medline

Diana MA, Levenes C, Mackie K, Marty A (2002) Short-term retrograde inhibition of GABAergic synaptic currents in rat Purkinje cells is mediated by endogenous cannabinoids. J Neurosci 22:200-208. Medline

Dinh TP, Carpenter D, Leslie FM, Freund TF, Katona I, Sensi SL, Kathuria S, Piomelli D (2002) Brain monoglyceride lipase participating in endocannabinoid inactivation. Proc Natl Acad Sci U S A 99:10819-10824. CrossRef Medline

Dwyer MA, Bredt DS, Snyder SH (1991) Nitric oxide synthase: irreversible inhibition by L-NG-nitroarginine in brain in vitro and in vivo. Biochem Biophys Res Commun 176:1136-1141. CrossRef Medline

East SJ, Garthwaite J (1990) Nanomolar N(G)-nitroarginine inhibits NMDA-induced cyclic GMP formation in rat cerebellum. Eur J Pharmacol 184:311-313. CrossRef Medline

Evans JH, Leslie CC (2004) The cytosolic phospholipase A2 catalytic domain modulates association and residence time at Golgi membranes. J Biol Chem 279:6005-6016. CrossRef Medline

Feil R, Hartmann J, Luo C, Wolfsgruber W, Schilling K, Feil S, Barski JJ, Meyer M, Konnerth A, De Zeeuw CI, Hofmann F (2003) Impairment of LTD and cerebellar learning by Purkinje cell-specific ablation of cGMPdependent protein kinase I. J Cell Biol 163:295-302. CrossRef Medline

Furfine ES, Harmon MF, Paith JE, Garvey EP (1993) Selective inhibition of constitutive nitric oxide synthase by L-NG-nitroarginine. Biochemistry 32:8512-8517. CrossRef Medline

Gallo V, Ciotti MT, Coletti A, Aloisi F, Levi G (1982) Selective release of glutamate from cerebellar granule cells differentiating in culture. Proc Natl Acad Sci U S A 79:7919-7923. CrossRef Medline

Han VZ, Grant K, Bell CC (2000) Reversible associative depression and nonassociative potentiation at a parallel fiber synapse. Neuron 27:611622. CrossRef Medline

Hansel C, Linden DJ, D'Angelo E (2001) Beyond parallel fiber LTD: the diversity of synaptic and nonsynaptic plasticity in the cerebellum. Nat Rev Neurosci 4:467-475. CrossRef Medline

Hansel C, de Jeu M, Belmeguenai A, Houtman SH, Buitendijk GH, Andreev D, De Zeeuw CI, Elgersma Y (2006) alphaCaMKII Is essential for cerebellar LTD and motor learning. Neuron 51:835-843. CrossRef Medline

Hartell NA (1996) Strong activation of parallel fibers produces localized calcium transients and a form of LTD that spreads to distant synapses. Neuron 16:601-610. CrossRef Medline

He M, Zhang ZH, Guan CB, Xia D, Yuan XB (2010) Leading tip drives soma translocation via forward F-actin flow during neuronal migration. J Neurosci 30:10885-10898. CrossRef Medline

Hoggatt J, Pelus LM (2010) Eicosanoid regulation of hematopoiesis and hematopoietic stem and progenitor trafficking. Leukemia 24:1993-2002. CrossRef Medline

Houk JC, Wise SP (1995) Distributed modular architectures linking basal ganglia, cerebellum, and cerebral cortex: their role in planning and controlling action. Cereb Cortex 5:95-110. CrossRef Medline 
Huang Y, Man HY, Sekine-Aizawa Y, Han Y, Juluri K, Luo H, Cheah J, Lowenstein C, Huganir RL, Snyder SH (2005) S-nitrosylation of $\mathrm{N}$-ethylmaleimide sensitive factor mediates surface expression of AMPA receptors. Neuron 46:533-540. CrossRef Medline

Ito M (2001) Cerebellar long-term depression: characterization, signal transduction, and functional roles. Physiol Rev 81:1143-1195. Medline

Jörntell H, Hansel C (2006) Synaptic memories upside down: bidirectional plasticity at cerebellar parallel fiber-Purkinje cell synapses. Neuron 52: 227-238. CrossRef Medline

Kreitzer AC, Regehr WG (2001) Retrograde inhibition of presynaptic calcium influx by endogenous cannabinoids at excitatory synapses onto Purkinje cells. Neuron 29:717-727. CrossRef Medline

Le TD, Shirai Y, Okamoto T, Tatsukawa T, Nagao S, Shimizu T, Ito M (2010) Lipid signaling in cytosolic phospholipase A2alpha-cyclooxygenase-2 cascade mediates cerebellar long-term depression and motor learning. Proc Natl Acad Sci U S A 107:3198-3203. CrossRef Medline

Lei SZ, Pan ZH, Aggarwal SK, Chen HS, Hartman J, Sucher NJ, Lipton SA (1992) Effect of nitric oxide production on the redox modulatory site of the NMDA receptor-channel complex. Neuron 8:1087-1099. CrossRef Medline

Leitges M, Kovac J, Plomann M, Linden DJ (2004) A unique PDZ ligand in PKCalpha confers induction of cerebellar long-term synaptic depression. Neuron 44:585-594. CrossRef Medline

Levenes C, Daniel H, Crépel F (1998) Long-term depression of synaptic transmission in the cerebellum: cellular and molecular mechanisms revisited. Prog Neurobiol 55:79-91. CrossRef Medline

Lev-Ram V, Makings LR, Keitz PF, Kao JP, Tsien RY (1995) Long-term depression in cerebellar Purkinje neurons results from coincidence of nitric oxide and depolarization-induced $\mathrm{Ca}^{2+}$ transients. Neuron 15: 407-415. CrossRef Medline

Lev-Ram V, Jiang T, Wood J, Lawrence DS, Tsien RY (1997) Synergies and coincidence requirements between NO, cGMP, and $\mathrm{Ca}^{2+}$ in the induction of cerebellar long-term depression. Neuron 18:1025-1038. CrossRef Medline

Lev-Ram V, Wong ST, Storm DR, Tsien RY (2002) A new form of cerebellar long-term potentiation is postsynaptic and depends on nitric oxide but not cAMP. Proc Natl Acad Sci U S A 99:8389-8393. CrossRef Medline

Lev-Ram V, Mehta SB, Kleinfeld D, Tsien RY (2003) Reversing cerebellar long-term depression. Proc Natl Acad Sci U S A 100:15989-15993. CrossRef Medline

Linden DJ (2003) From molecules to memory in the cerebellum. Science 301:1682-1685. CrossRef Medline

Linden DJ, Ahn S (1999) Activation of presynaptic cAMP-dependent protein kinase is required for induction of cerebellar long-term potentiation. J Neurosci 19:10221-10227. Medline

Lisman J (1989) A mechanism for the Hebb and the anti-Hebb processes underlying learning and memory. Proc Natl Acad Sci U S A 86:95749578. CrossRef Medline

Maejima T, Oka S, Hashimotodani Y, Ohno-Shosaku T, Aiba A, Wu D, Waku K, Sugiura T, Kano M (2005) Synaptically driven endocannabinoid release requires $\mathrm{Ca}^{2+}$-assisted metabotropic glutamate receptor subtype 1 to phospholipase Cbeta4 signaling cascade in the cerebellum. J Neurosci 25:6826-6835. CrossRef Medline

Malcher-Lopes R, Franco A, Tasker JG (2008) Glucocorticoids shift arachidonic acid metabolism toward endocannabinoid synthesis: a non-genomic anti-inflammatory switch. Eur J Pharmacol 583:322-339. CrossRef Medline

Medina JF, Nores WL, Ohyama T, Mauk MD (2000) Mechanisms of cerebellar learning suggested by eyelid conditioning. Curr Opin Neurobiol 10:717-724. CrossRef Medline

Okamoto Y, Morishita J, Tsuboi K, Tonai T, Ueda N (2004) Molecular characterization of a phospholipase D generating anandamide and its congeners. J Biol Chem 279:5298-5305. CrossRef Medline
Piochon C, Levenes C, Ohtsuki G, Hansel C (2010) Purkinje cell NMDA receptors assume a key role in synaptic gain control in the mature cerebellum. J Neurosci 30:15330-15335. CrossRef Medline

Safo PK, Regehr WG (2005) Endocannabinoids control the induction of cerebellar LTD. Neuron 48:647-659. CrossRef Medline

Salin PA, Malenka RC, Nicoll RA (1996) Cyclic AMP mediates a presynaptic form of LTP at cerebellar parallel fiber synapses. Neuron 16:797-803. CrossRef Medline

Schonewille M, Belmeguenai A, Koekkoek SK, Houtman SH, Boele HJ, van Beugen BJ, Gao Z, Badura A, Ohtsuki G, Amerika WE, Hosy E, Hoebeek FE, Elgersma Y, Hansel C, De Zeeuw CI (2010) Purkinje cell-specific knockout of the protein phosphatase PP2B impairs potentiation and cerebellar motor learning. Neuron 67:618-628. CrossRef Medline

Sejnowski TJ (1977) Statistical constraints on synaptic plasticity. J Theor Biol 69:385-389. CrossRef Medline

Shin JH, Linden DJ (2005) An NMDA receptor/nitric oxide cascade is involved in cerebellar LTD but is not localized to the parallel fiber terminal. J Neurophysiol 94:4281-4289. CrossRef Medline

Stamler JS, Toone EJ, Lipton SA, Sucher NJ (1997) (S)NO signals: translocation, regulation, and a consensus motif. Neuron 18:691-696. CrossRef Medline

Stefano GB, Hartman A, Bilfinger TV, Magazine HI, Liu Y, Casares F, Goligorsky MS (1995) Presence of the mu3 opiate receptor in endothelial cells: coupling to nitric oxide production and vasodilation. J Biol Chem 270:30290-30293. CrossRef Medline

Steinberg JP, Takamiya K, Shen Y, Xia J, Rubio ME, Yu S, Jin W, Thomas GM, Linden DJ, Huganir RL (2006) Targeted in vivo mutations of the AMPA receptor subunit GluR2 and its interacting protein PICK1 eliminate cerebellar long-term depression. Neuron 49:845-860. CrossRef Medline

Su LD, Shen Y (2009) Blockade of glutamate transporters facilitates cerebellar synaptic long-term depression. Neuroreport 20:502-507. CrossRef Medline

Su LD, Sun CL, Shen Y (2010) Ethanol acutely modulates mGluR1dependent long-term depression in cerebellum. Alcohol Clin Exp Res 34:1140-1145. CrossRef Medline

Sun CL, Su LD, Li Q, Wang XX, Shen Y (2011) Cerebellar long-term depression is deficient in Niemann-Pick type C disease mice. Cerebellum 10:8895. CrossRef Medline

Takahashi KA, Linden DJ (2000) Cannabinoid receptor modulation of synapses received by cerebellar Purkinje cells. J Neurophysiol 83:1167-1180. Medline

Takechi H, Eilers J, Konnerth A (1998) A new class of synaptic response involving calcium release in dendritic spines. Nature 396:757-760. CrossRef Medline

van Beugen BJ, Nagaraja RY, Hansel C (2006) Climbing fiber-evoked endocannabinoid signaling heterosynaptically suppresses presynaptic cerebellar long-term potentiation. J Neurosci 26:8289-8294. CrossRef Medline

Wang DJ, Yang D, Su LD, Xie YJ, Zhou L, Sun CL, Wang Y, Wang XX, Zhou L, Shen Y (2012) Cytosolic phospholipase A2 alpha/arachidonic acid signaling mediates depolarization-induced suppression of excitation in the cerebellum. PLoS One 7:e41499. CrossRef Medline

Wang YT, Linden DJ (2000) Expression of cerebellar long-term depression requires postsynaptic clathrin-mediated endocytosis. Neuron 25:635647. CrossRef Medline

Xia J, Chung HJ, Wihler C, Huganir RL, Linden DJ (2000) Cerebellar longterm depression requires PKC-regulated interactions between GluR2/and PDZ domain-containing proteins. Neuron 28:499-510. CrossRef Medline

Yao JA, Jiang M, Tseng GN (1997) Mechanism of enhancement of slow delayed rectifier current by extracellular sulfhydryl modification. Am J Physiol 273:H208-H219. Medline 